\title{
EFFECT OF 1-METHYLCYCLOPROPENE AND HOT WATER TREATMENTS ON RETARDING RIPENESS OF CANTALOUPE FRUITS DURING COLD STORAGRE
}

\author{
ATRESS, AMAL S. H. AND M. M. ATTIA \\ Postharvest and Handling of vegetable crops Department, Horticulture Research \\ Institute, ARC, Giza, Egypt
}

(Manuscript received 21 June 2011)

\begin{abstract}
Melon plants (Cucumis melo) cv. Galia primal were grown under tunnels during 2008/2009 and 2009/2010 seasons in Fayed district, Ismailia Governorate. The fruits were _harvested at light yellow with green coloring stage, treated with 0.05 or $0.1 \mathrm{mg} / \mathrm{l} 1$ Methylecyclopropene (1-MCP) by immersing fruits for $5 \mathrm{~min}$. or treated with hot water at $52^{\circ} \mathrm{C}$ for $5 \mathrm{~min}$. or $56^{\circ} \mathrm{C}$ for $2 \mathrm{~min}$. and untreated (control fruits). All fruits were stored at $5^{\circ} \mathrm{C}+95 \% \mathrm{RH}$ for 21 days in addition to 2 days at $15^{\circ} \mathrm{C}+95 \% \mathrm{RH}$ (shelf life simulation).

Results showed that quality parameters which include general appearance, total sugars, reducing sugars, titratable acidity, and TSS were decreased during storage while weight loss, decay and color ( $b$ value) were increased with the prolonging of the storage period.

Application of 1-MCP at $0.05 \mathrm{mg} / \mathrm{l}$ treatment delayed fruit ripening, through reducing the development of softening comparing with the other treatments. In addition, this treatment maintained the good appearance as well as the previously-mentioned quality characteristics till 21 days of storage at $5^{\circ} \mathrm{C}+2$ days at $15^{\circ} \mathrm{C}+95 \%$ $\mathrm{RH}$ comparing with the others treatments.
\end{abstract}

\section{INTODUCTION}

The Galia melon fruit is a climacteric fruit in which ripening is highly coordinated by ethylene (Seymour and McGlasson, 1993). Ripening of most climactric fruits is characterized by softening of flesh, an increase in the sugar/acid ratio, enhance color development, an increases in respiratory activity and ethylene production. Exposure to ethylene of either endogenous or external sources can reduce the postharvest life of climacteric and other fruit and vegetables by accelerating ripening or senescence process (Reid, 1985). To date, 1-MCP seems to be the most practical ethylene action inhibitor due to its stability, effectiveness at low concentrations, short treatment duration and nontoxic properties. The compound has been used successfully to prevent ethylene effects in a wide variety of fruit and vegetables (Blankship and Dole, 2003). Furthermore, studies have confirmed that 1 MCP treatment can be effective when applied after the ignition of ripening (Hoeberichts et. al., 2002, Mir et. al., 2003, Wills and Ku, 2002). 
Hot water treatment of a number of horticulture crops has been demonstrated to be effective in product shelf life improvement (Lurie, 1998), control of microbial contamination, insect infestations and quarantine treatment in melon fruit (Fallik, et. al. (2000) and Fallik (2004), prevented growth of lactic acid bacteria and improve the shelf life of cantaloupe melon (Lamikanra and Watson, 2007), and control activity of pathogens (Cantwell and Nie, 1992). Thus, it has been used as a supplement to refrigeration to extend storage and shelf life of cantaloupe fruits (Rageh, 2003). Therefore, the aim of this study was to determine the effects of postharvest application of 1-methylecyclopropene (1-MCP) and hot water treatment on the changes in properties related to cantaloupe quality when applied at the light yellow with green coloring stage during prolonged storage.

\section{MATERIALS AND METHODS}

Plants of melon (Cucumis melo L.) Galia Primal cultivar were grown in winter season under tunnels during 2008/2009 and 2009/2010 seasons in Fayed district, Ismailia Governorate. The fruits were harvested at light yellow with green coloring stage (color stage 3) according to Fallik et. al. (2001) on April 8 and 13 in the two seasons, respectively, and were kept overnight at $5^{\circ} \mathrm{C}+95 \% \mathrm{RH}$.

The following day uniform fruits in color and size were chosen and randomly distributed into five groups as follows:

1. Control fruits (untreated).

2. Dipped fruits in $1-\mathrm{MCP}$ at the concentrations of $0.05 \mathrm{mg} / \mathrm{l}$ for $5 \mathrm{~min}$.

3. Dipped fruits in 1-MCP at the concentrations of $0.1 \mathrm{mg} / \mathrm{l}$ for $5 \mathrm{~min}$.

4. Dipped fruits in hot water of $52^{\circ} \mathrm{C}$ for $5 \mathrm{~min}$.

5. Dipped fruits in hot water of $56^{\circ} \mathrm{C}$ for $2 \mathrm{~min}$.

After immersing fruits either in 1-MCP treatments or hot water treatments, the fruits were left for drying then packed in carton boxes at the diminutions of $30 * 15 * 10 \mathrm{~cm}$ as one replicate, nine replications for each treatment were stored at $5^{\circ} \mathrm{C}+95 \% \mathrm{RH}$ for 21 days in addition to 2 days at $15^{\circ} \mathrm{C}+95 \% \mathrm{RH}$ (shelf life simulation). The sample for each treatment was taken at random in three replications and arranged in a complete randomized design. Samples were evaluated for the changes in the quality parameters during storage.

\section{The following data were recorded}

1. Weight loss percentage was estimated according to the following equation:

Weight loss $\%=$ initial fruit weight - fruit weight at sampling date / initial fruit weight $* 100$. 
2. Decay percentage was estimated as the number of decayed fruits / total count of fruits $* 100$.

3. General appearance was determined according to the following score system: $9=$ excellent, $7=$ good, $5=$ fair, $3=$ poor, and $1=$ unusable. This scale depend on morphological defects such as shriveling (wilting), color change of fruit surface and the physiological defects.

4. External surface color was evaluated by a color difference meter (Minolta CR200) to measure the $b$ value.

5. Firmness was measured after peeling the fruit skin, the reading was the average for 3 reading along the fruit surface using pentrometer (EFEEG1) in $\mathrm{lb} \backslash$ inch $^{2}$ and converted to Newton "N" (as recommended by ASHS postharvest working group) (Abbott et al., 1976).

6. Total soluble solids percentage were measured by the digital refractometer, "Model Abbe Lecia"

7. Titratable acidity percentage in pulp was measured by titration with $0.1 \mathrm{NaOH}$ and calculated as citric acid according to AOAC (1990).

8. Total and reducing sugars were measured according to Somogyi (1952) and Nelson (1974).

All obtained data were statistically analyzed according to the method described by Snedecor and Cochran (1980).

\section{RESULTS AND DISCUSSION}

\section{Weight loss \%}

Data in Table (1) showed that weight loss percentage of cantaloupe fruits increased considerably and consistently with the prolongation of storage period. The weight loss is natural consequence of the catabolism of horticulture products, the loss in weight may be attributed to respiration and other senescence related metabolic processes during storage (Watada and $Q i$, 1999). Similar results were reported by Ramadan et al. (2008). However, 1-MCP treatments had significant effect on weight loss percentage. This treatment reduced the loss in weight of cantaloupe fruit during storage. Moreover, 1-MCP at $0.05 \mathrm{mg} / \mathrm{l}$ was the most effective treatment. This result agrees with Guillen et. al. (2006) who found that 1-MCP treatment was highly effective in reducing weight loss in tomato fruit. Minimizing weight loss of cantaloupe fruits during storage with $1-\mathrm{MCP}$ treatment may be due to that 1-MCP significantly delayed the onset of climacteric ethylene production and respiration rate in cantaloupe fruit during storage (Francisca et. al., 2008) which diminished the weight 
loss in fruits during storage (Muharrem et. al., 2005). On the contrary, dipping cantaloupe fruits in hot water led to increasing the percentage of weight loss as compared with the other treatments or untreated fruit control. In this respect, dipping cantaloupe fruits in hot water of $56^{\circ} \mathrm{C}$ for 2 min gave the highest value of weight loss during storage. These results are similar to those reported by Rageh (2003) who found that dipping cantaloupe fruits in hot water increased the weight loss percentage during storage. These results might be attributed that dipping fruits in hot water increased respiration rate following treatment and during storage and subsequently increase fruit weight loss (McCollum et al., 1995). The interaction between postharvest treatments and storage period showed that 1-MCP treatments decreased weight loss percentage of fruits during all storage period compared to other treatments.

\section{Decay \%}

A progressive and continuous increase in percentage of decay was noticed till the end of storage period in both seasons (Table 1). This finding may be due to the continuous chemical and biochemical changes happened in fruits such as moisture concentration and transformation of complex compounds to simple forms of more liability to fungal infection such as solid protection to the soluble pectin form (Wills et al., 1981). These results are in harmony with those obtained by Ramadan et al., (2008). However, no decayed fruits were observed in cantaloupe fruits treated with 1MCP $(0.05$ or $0.1 \mathrm{mg} / \mathrm{l})$ or dipped in hot water at $52^{\circ} \mathrm{C}$ for $5 \mathrm{~min}$. all over the storage period in both seasons. Dipping fruits in hot water resulted in some decrease in fungal development which may be related to washing of some of the natural pathogenic spore population from the surface of the fruits. However, such a dip may also remove part of the natural antagonistic flora inhabiting the fruit peel which may act as a bio control agent for postharvest pathogens (Cantwell and Nie, 1992). However, dipping cantaloupe fruits in hot water at $56^{\circ} \mathrm{C}$ for $2 \mathrm{~min}$. increased cantaloupe susceptibly to postharvest decay (Table1). This increase in postharvest decay susceptibility may be resulted from the heat damage to the epidermal cells, which allow the easy access and establishment of pathogen (Harvey et al., 1989 on cucumber).

The interaction between treatments and storage period on decay percentage were significant in both seasons indicating that fruits treated with 1-MCP or hot water at $52^{\circ} \mathrm{C}$ for $5 \mathrm{~min}$. did not show any decay symptoms all over the storage period.

\section{General appearance}

Data presented in Table (2) showed that general appearance score decreased with prolonging the storage period significantly and that was true for the two seasons. Such decrease in general appearance, mostly may be due to a slight dryness of the 
surface, instead of translucency or macroscopic decay, as expected. It is clear that fruits treated with, 1-MCP maintained good general appearance followed by hot water treatment at $52^{\circ} \mathrm{C}$ for $5 \mathrm{~min}$ compared to untreated (control) fruits which deteriorated rapidly. The most effective treatment was $0.05 \mathrm{mg} / \mathrm{l} 1-\mathrm{MCP}$.

The interaction between the postharvest treatments and the storage period was significant during storage and shelf life condition. So cantaloupe fruit treated with 1-MCP $0.05 \mathrm{mg} / \mathrm{l}$ did not exhibit any changes in their appearance till the 14 days at $5^{\circ} \mathrm{C}+2$ days at $10^{\circ} \mathrm{C}$ and gave fruits with good appearance at the end of the storage period. Mean while fruits treated with $1-\mathrm{MCP} 0.1 \mathrm{mg} / \mathrm{l}$ or immersed in hot water at $52^{\circ} \mathrm{C}$ for 5 min. gave fruits with good appearance after 14 days at $5^{\circ} \mathrm{C}+2$ days at $10^{\circ} \mathrm{C}$. However, untreated control resulted in good appearance after 7 days at $5^{\circ} \mathrm{C}+2$ days at $10^{\circ} \mathrm{C}$ and dropped to poor level at the end of storage period.

\section{Color ( $b$ value)}

Data in Table (2) indicated that significant increase in b value was noticed with prolonging the storage period in the two seasons. The color of cantaloupe fruits became yellow to orange with the storage time, which may be due to the breakdown of chlorophyll and synthesis of carotinoides, a pigment contributing to orange color in cantaloupe fruit (Muharrem et al., 2005). As for the postharvest treatments, data revealed that untreated control and hot water treatment fruits had developed a uniformly yellow appearance (color stage 5) according to Fallik et al., (2001) after 14 days at $5^{\circ} \mathrm{C}+2$ days at $10^{\circ} \mathrm{C}$ and had developed a full orange appearance (color stage 6 ) at the end of storage (the highest b value). In contrast, the surface color of 1-MCP treated fruits never exceeded light yellow color (the lowest $b$ value) at the end of storage period. However, treating cantaloupe fruits with $1-\mathrm{MCP}$ at $0.05 \mathrm{mg} / \mathrm{l}$ was the most effective for reducing changes of color. These results are similar to those of Muharrem et al. (2005) who reported that cantaloupe fruits treated with 1-MCP delayed fruit ripening and reduce color change, thus extending the shelf life of cantaloupe fruits.

Jiang and $\mathrm{Fu},(2000)$ found that differential effects of 1-MCP on colour development depend on the multiplicity of pigment changes contributing to final fruit color (chlorophyll degradation, selective pigment synthesis, or both) and their relative dependency on ethylene responsiveness. Also, they added that the inability of 1-MCP treated fruits to fully express all ethylene-induced ripening parameters is consistent with reports that 1-MCP acts as high affinity noncompetitive inhibitor of ethylene action.

The interaction between postharvest treatments and the storage period was significant. Cantaloupe fruits treated with $0.05 \mathrm{mg} / \mathrm{l} 1$-MCP showed the lowest color 
change (the lowest $b$ value) compared to other treatments during storage at $5^{\circ} \mathrm{C}$ for 21 days +2 days at $10^{\circ} \mathrm{C}$.

\section{Firmness}

Data in Table (3) revealed that significant reduction in fruit firmness had occurred by prolongation of the storage period. This result agrees with those obtained by Ramadan et al. (2008) on cantaloupe.

The decrease in fruit firmness may be due to gradual breakdown of protopectin to lower molecular weight fractions which are more soluble in water and this is directly correlated with the rate of softening of the fruits (Wills et al., 1981).

Concerning various treatment, cantaloupe fruits treated with 1-MCP $(0.05$ or $0.1 \mathrm{mg} / \mathrm{l}$ ) were firmer than those of hot water treatment or control. However, 1-MCP treatment with $0.05 \mathrm{mg} / \mathrm{l}$ was the most effective treatment. These results were in agreement with those obtained by Blankship and Dole (2003) who found that the application of 1-MCP on cantaloupe fruits reduced tissue softening in fruits. Muharrem et al. (2005) found that the 1-MCP induced firmness retention was accompanied by significant suppression of electrolyte leakage of mesocarp tissue, providing evidence that membrane dysfunction might contribute to softening of Galia melon.

The interaction between the storage period and postharvest treatments revealed that 1-MCP treatments maintained fruit firmness than hot water treatments or untreated (control) fruits till the end of storage period.

\section{Titratable acidity}

Data in Table (4) showed that titratable acidity content in cantaloupe fruits decreased gradually with the prolongation of storage period. These results were in agreement with those obtained by Rageh (2003). The reduction in fruit acidity during storage might be attributed to the rapid rate of oxidation of pyruvic acid and other acids to carbon dioxide (Wills et al., 1981).

Concerning treatments application, data revealed that cantaloupe fruits treated with $1-\mathrm{MCP}$ at $0.05 \mathrm{mg} / \mathrm{l}$ had significantly reduced titratable acidity loss during storage and gave the highest value, however, hot water treatments and untreated control gave the lowest ones .Reducing titratable acidity loss, as observed in 1-MCP treatment, may indicate stability of metabolic reactions, such as respiration and production of volatiles under anaerobic conditions, once those acids may serve as substrate in such reactions ( Francisca et. al., 2008).

The interaction between the storage period and the postharvest treatments indicated that after 21 days of storage +2 days (shelf life), 1-MCP at $0.05 \mathrm{mg} / \mathrm{l}$ preserved the highest titratable acidity compared with the other postharvest treatments. 


\section{Total soluble solids(TSS), reducing and total sugars}

Data in Tables ( 4 \& 5) showed that TSS, reducing and total sugar percentages of cantaloupe fruits were significantly affected by the storage period. There was a significant reduction in the mentioned parameters by the prolongation of storage period in both seasons. These results are in agreement with those of Rageh (2003) on cantaloupe fruits.

The reduction in TSS, reducing and total sugars content during storage may be due to the higher rate of sugar loss through respiration than the water loss through transpiration (Wills et. al., 1981).

Regarding the effect of postharvest treatments, data revealed that cantaloupe fruits treated with $1-\mathrm{MCP}(0.05$ or $0.1 \mathrm{mg} / \mathrm{l})$ retained more TSS, reducing and total sugar percentages compared to hot water treatments and untreated (control) fruits. Moreover, 1-MCP at $0.05 \mathrm{mg} / \mathrm{l}$ was the most effective treatment. These results may be explained on the basis that using 1-MCP reduced respiration rate and physiological changes of fruits during storage (Muharrem et. al., 2005).

The interaction between treatments and the storage period data revealed that cantaloupe fruits treated with $1-\mathrm{MCP}$ at $0.05 \mathrm{mg} / \mathrm{l}$ maintained the highest TSS, reducing and total sugar percentages during all storage periods.

\section{CONCLUSION}

From the previous results it could be concluded that 1-MCP treatment at the concentration of $0.05 \mathrm{mg} / \mathrm{l}$ was the most effective treatment for delaying fruit ripeness among the other postharvest treatments throughout reducing fruit weight loss, decay, developing of softening, fruit surface color, loss of total and reducing sugars and maintaining good appearance, and high acidity up to 21 days at $5^{\circ} \mathrm{C}$ plus 2 days at $10^{\circ} \mathrm{C}$. 
Table 1 
Table 2 
Table 3 
Table 4 
Table 5 


\section{REFERENCES}

1. Abbot, J. A. 1976. Quality m easurements of fruits and vegetables. Postharvest Biol. Technol.15: 207-225.

2. A.O.A.C. 1990. Quality of Official Analytical Chemists, Washington DC. USA.

3. Blankenship, S. M. and J. M. Dol. 2003. 1-Methylcyclopropene: A Rview. Postharvest Biol. Technol. 28: 1-25.

4. Cantwell, M. and X. Nie. 1992. Use of heat treatment to control postharvest pathogens on tomato and melons. Proceeding of the Organic Farming University. Of California Publication 3356: 96-101.

5. Fallik, E. 2004. Prestorage hot water treatments (Immersion, rinsing and brushing). Postharvest. Biol.Technol.32: 125-134.

6. Falik, E., Y. Aharoni, A. Copel, R.Rodov, S. Tuvia-Alkalai, and B. Horev. 2000. A short hot water rinse reduces postharvest losses of (Galia) melon. Plant Pathology 49: 333-338.

7. Fallik. E., S. Alkali-Tuvia, Horev., A. Copel, V. Rodov, Y. Aharoni, D. Ulrich, and H. Schulz. 2001. Chractreization of Galia melon aroma by GC and mass spectrometric sensor measurement after prolonged storage. Postharvest. Biol. Technol. 22: 8591.

8. Francisca, M., R. E. Alves and R. F. Figueredo. 2008. Application of 1methylcyclopropen,calcium chloride and calcium amino acid chelate on fresh-cut cantaloupe muskmelon.Postharvest Biol.Technol. 48: 242-252.

9. Guillen, F., S. Castillo, G. Bailen, D. Martinez-Romero, P. J. Zapata, M. Serano and D.Valero. 2006. Efficacy of 1-MCP treatment in tomato fruit. 2. Effect of cultivar and ripening stage at harvest. Postharvest Biol. Technol. 42: 235-242.

10. Harvey,T., J. R. Chan and E. Linse (1989). Condition cucumber for Quarantine heat treatments. HortScince. 24 (6): 958-989.

11. Hoeberichts, F. A., L. H. W. VanDerPlas and W.J. Woltering. 2002. Ethylene reception is required for expression of tomato ripening related genes and associated physiological changes even at advanced stages of ripening. Postharvest. Biol. Technol. 26: 125-133.

12. Jiang, Y. and J. Fu. 2000. Ethylene regulation of fruit ripening: Molecular aspects. Plant Growth Regulat. 30: 193-200.

13. Lamikanra, O. and M. A. Waston. 2007. Mild heat and calcium treatment effects on fresh-cut cantaloupe melon during storage. Food Chemistry 102: 1383-1388.

14. Lurie, S. 1998. Postharvest heat treatments. Postharvest Biol. Technol. 14: 257269. 
15. McCollum,T. G., H. Doostda, R. T. Moyer and R. E. McDonald. 1995. Immersion of cucumber fruit in heated water alters chilling induced physiological changes. Postharvest Biol. Technol.6: 55-64.

16. Mir, M., M. Canoles, R. Beaudry, E. Baldwin and C. P. Mehla. 2003. Inhibition of tomato ripening by 1-methylcyclopropene. J. Amer. Soc. Hort. Sci. 129: 112-120.

17. Muharrem. E., J. Jeong, D. J. Huber and D. J. Canliffe. 2005. Suppression of ripening and softening of Galia melons by 1-Methylcyclopropene applied at preripe or ripe stages of development. HortScince. 40 (1): 170-175.

18. Nelson, N. 1974. A photometric adaptation of Somogyi methods for Determination of glucose. J. Biology Chem., 159: 375 - 380 .

19. Rageh, M. A. 2003. Physiological studies on cantaloupe production in sandy soil and storage ability of fruits. Ph.D. Thesis, Fac. Agric. Cairo Univ., Egypt.

20. Ramadan, A. Y., Y. T. El-Lithy and M. A. Rageh. 2008. Effect of slow release nitrogen fertilizers with foliar potassium and calcium application during fruit development on growth, yield, sugar content, nitrate accumulation and storage ability in melon. J. Agric. Sci. Mansoura Univ., 33 (9): 6687-6706.

21. Reid, M. S. 1985. Ethylene in postharvest technology, p. 68 -74. In: A.A.Kader, R.F. Kasmire, S.G.Mitchel, and M.S.Reid (eds.). Postharvest Technology of Horticultural Crops.Univ.Calif. Berkley.

22. Seymour, G. B. and W. B. McGlasson. 1993. Melons, p. 273-290. In: G. Seymour, J. Taylor, and G. Tucker (eds.). Biochemistry of fruit ripening. Chapman and Hall, Cambridge Univ. Press, Cambridge, U.K.

23. Snedecor, G. W. and W. G. Cochran. 1980. Statistical methods. Iowa State Univ. Press, USA.

24. Somogyi, M. 1952. Notes on sugar determination, Jour. Biology Chem., 195: 1923.

25. Watada, A. E. and L. Qi. 1999. Quality of fresh-cut produce. Postharvest Biol. Technol. 15: 201-205.

26. Wills, R. B. H. and V. V. V. Ku. 2002. Use of 1-MCP to extend the time to ripen of green tomatoes and postharvest life of ripe tomatoes. Postharvest Biol. Technol. 26: 85-95.

27. Wills, R. B. H., T. H. Lee, D. Gerham, W. B. McGlesson and E. G. Hall. 1981. Postharvest An introduction to physiology and handling of fruits and vegetables. Inc Westport, Connectiut. 


\section{تأثير المعاملة بالميثيل سيكلو بروبان والماء الساخن على تأخير نضج ثمار الكنتالوب أثناء التخزين المبرد}

\section{أمل سبد حسن عتريس منال محمد عطية}

قسم معاملات ما بعد الحصاد و تداول الخضر - معرج بحوث البساتين مركز البحوث الزرراعية الجيزة - مصر.

تم زر اعة الكنتالوب صنف بريمال تحت الانفاق بمركز فايد بمحافظة الاسماعيلية خلال

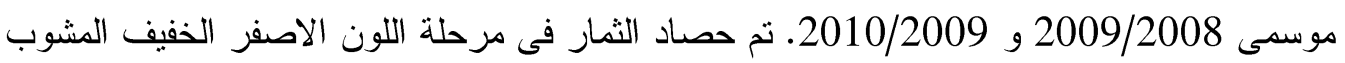
باللون الاخضر حيث تم معاملتها بغس الثمار فى محلول 1-ميثيل سيكلو بروبان 0.050 .0

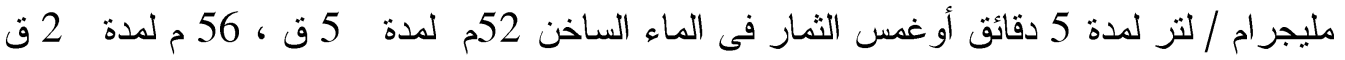
بالاضافة الى ثمار غير معاملة ( كنترول ). ثم تخزين المعاملات السابقة على

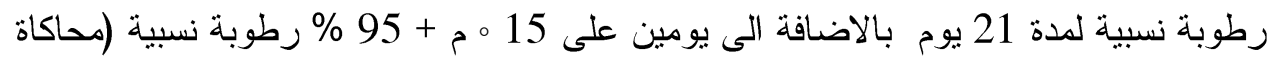
لإنعرض بالأسواق )

وقد بينت النتائج إنخفاض المظهر العام للثمار وكذلك السكريات الكليه و المختزله

و الحموضه ونسبة المو اد الصلبه الذائبه الكليه بزيادة مدة التخزين، بينما زادت النسبه المئويه لفقد الوزن ونسبة التالف ودرجة نضج الثمار مع زيادة طول فترة التخزين.

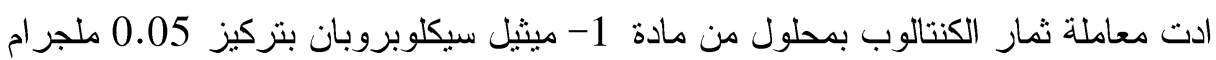

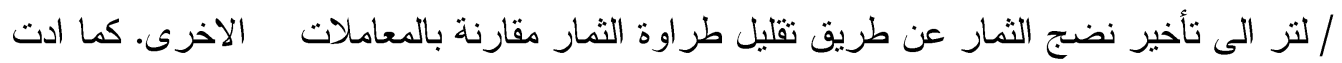

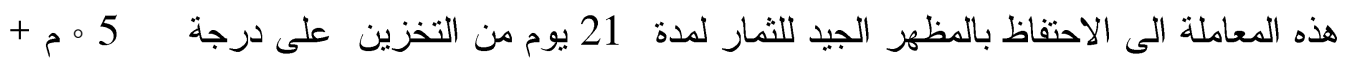
95\% رطوبة نسبية بالاضافة الى يومين على درجة 15 م م + 95 \% رطوبة بلهية نسبية مقارنة

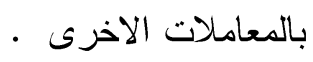

